\title{
Alternative Methods of Calculating Optimal Timber Rotations: A Critique of the Stokey/Lucas/Prescott Tree-Cutting Problem
}

\author{
By \\ Victor A. Matheson \\ January 2007

\section{COLLEGE OF THE HOLY CROSS, DEPARTMENT OF ECONOMICS \\ FACULTY RESEARCH SERIES, PAPER NO. 07-01*}

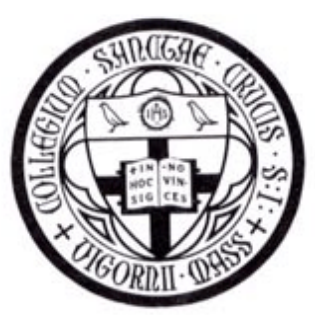

Department of Economics

College of the Holy Cross

Box 45A

Worcester, Massachusetts 01610

(508) 793-3362 (phone)

(508) 793-3710 (fax)

http://www.holycross.edu/departments/economics/website

*All papers in the Holy Cross Working Paper Series should be considered draft versions subject to future revision. Comments and suggestions are welcome. 


\title{
Alternative Methods of Calculating Optimal Timber Rotations: A Critique of the Stokey/Lucas/Prescott Tree-Cutting Problem
}

\author{
By \\ Victor A. Matheson ${ }^{\dagger}$ \\ College of the Holy Cross
}

January 2007

\begin{abstract}
The traditional question of optimally deciding when to cut down a tree is among the most commonly posed questions asked of students learning the technique of dynamic programming. This paper shows that the traditional tree-cutting example is improperly formulated when the question of replanting is addressed, derives the proper method of finding optimal harvest length, and applies this method to an empirical forest growth function.
\end{abstract}

JEL Classification Codes: D81, H71, L83

Keywords: forestry, dynamic programing, tree cutting problem

Note: This paper is a revision of a paper written in 1995 and presented at the University of Minnesota Environmental Science and Engineering Conference, Minneapolis, MN, May 1997.

${ }^{\dagger}$ Victor A. Matheson, Department of Economics, Box 157A, College of the Holy Cross, Worcester, MA 01610-2395, 508-793-2649 (phone), 508-793-3710 (fax), vmatheso@holycross.edu 


\section{Introduction}

The traditional question of optimally deciding when to cut down a tree is among the most commonly posed questions asked of students learning the technique of dynamic programming. This paper shows that the traditional tree-cutting example is improperly formulated when the question of replanting is addressed, derives the proper method of finding optimal harvest length, and applies this method to an empirical forest growth function.

The standard model, as shown in Stokey, Lucas, and Prescott (1989), asks the student to consider a tree whose growth is described by the function $h$. That is, if the size of the tree in period $t$ is $k_{t}$, then $k_{t+1}=h\left(k_{t}\right) t=1,2, \ldots$. The price of wood is assumed to be constant over time and is normalized to 1 . The discount rate, $r$, is also constant over time ${ }^{1}$ and $\beta=1 /(1+r)$. Finally, it is costless to cut down the tree.

If the tree cannot be replanted, present value maximization leads to the functional equation $v(k)=\max \{k, \beta v[h(k)]\}$. Under the assumptions that $h$ is continuous, concave, and monotonically decreasing in $k$, and the assumption that $0<\beta<1$, it is easily shown that $v(k)$ is a contraction mapping and therefore has a unique solution. The solution leads to a simple rule that the tree should be cut down when the growth rate of the tree $=r$.

Difficulties arise, however, when the issue of replanting is raised. The extension of the question asks the student to assume that once the tree is cut down it can be replanted. These replanted trees can then be cut down and replanted infinitely into the future. The cost of

${ }^{1}$ Alvarez and Koskela (2003) examine the tree cutting problem while relaxing the assumption of constant interest rates. 
replanting is assumed to be $C \geq 0$ and is constant over time. Now, one solves for the optimal harvest and replanting rules.

The standard textbook answer is that the optimal harvest decision is to cut when the rate of growth for the tree $=r$. The tree-cutter then decides whether or not to replant with the decision rule being to replant if $C \leq v(0)$ under the optimal cutting rule, and not to replant if $C>v(0)$. In other words, the tree-cutter first decides when the optimal time to cut is and then decides whether or not to replant. Unfortunately, this decision-making process will not in general lead the tree-cutter to maximize his/her discounted value from harvesting in the forest and can lead to substantially sub-optimal rotation lengths for the stand of trees.

A fully rational infinitely-lived consumer will consider the option of replanting when first making the decision to cut, not as an independent decision once the trees are already felled. Thus, the functional equation for present value maximization changes from a two-part optimization question to a single functional equation. In each period, the tree-cutter has three options: 1. leave the trees for later harvest; 2 . cut the trees and replant; 3. cut the trees and don't replant. The functional equation becomes $v(k)=\max \{\beta v[h(k)], k+v(0)-C, k\}$. There is no simple rule regarding the optimal harvest time, and one cannot even determine whether the standard method leads to shorter or longer harvest lengths than the revised model. The use of a numerical example, however, serves to illustrate the differences between the standard and revised functional equations.

\section{An Empirical Example}


Based on a numerical example provided by Clawson (1977), it is assumed that the mathematical function relating volume of wood to time in a stand of Douglas fir can be represented by a third-degree polynomial of the form $V=40 t+3.1 t^{2}-.016 t^{3}$. The volume of new growth is any period is $\delta V / \delta t=40+6.2 t-.048 t^{2}$. Finally the percentage increase in growth for a given period is then $(\delta V / \delta t) / V=\left(40+6.2 t-.048^{2}\right) /\left(40 t+3.1 t^{2}-.016 t^{3}\right)$. Initially, it will be assumed that there are no cutting or replanting costs associated with the harvest of wood. This simplifies the problem considerably by eliminating the decision to replant in the forester's problem. With no replanting or cutting costs, the forester will clearly always decide to replant once the decision is made to cut.

Under the standard model, the timber is cut when the growth rate is equal to the exogenously determined discount rate, $r$. The optimal cutting time for this model for a number of potential discount rates is summarized in Table 1.

A second common rule used the formulation of optimal rotation lengths is the concept of Mean Annual Increment (MAI). This cutting rule, utilizing a purely biological basis, endeavors to maximize the total amount of wood that is gathered from the forest over time. To find the maximum mean annual increment one simply finds the year, $t$, such that the volume of the wood in the stand divided by the age is maximized. In this example, this involves maximizing $V / t$ or $\max \left\{\left(40 t+3.1 t^{2}+.016 t^{3}\right) / t\right\}$ resulting in a cutting time of 97 years.

Notice that in this purely biological model there is no mention of the discount rate so that the maximum MAI is independent of the rate of time preference. For this reason, economists have generally rejected this method of rotation length determination. This method has some 
interesting comparisons to the standard and revised cutting models presented in this paper, however, so it is included for this reason.

Finally, to solve for the optimal cutting time in the revised model one must choose $t$ to maximize the discounted value of the infinite series of cuts performed at a regular interval of $t$ years. This function is expressed in equation (1).

$$
\max \sum_{n=1}^{\infty} \frac{V(t)}{(1+r)^{t n}} \quad \text { w.r.t. } t
$$

This equation cannot be solved analytically. Numerically calculated solutions for a number of discount rates are shown in Table 1.

Table 1 provides two interesting items of note. First, the revised method, when there are no harvesting or replanting costs, always leads to a shorter cutting length than the standard method. The intuition behind this is that for the particular forest growth function used, the trees grow rapidly when young and then growth slows as the stand grows older. ${ }^{2}$ The revised model accounts for the rapid growth of the tree when they are young, and therefore trees are cut down sooner than in the standard method in order to make room for the new generation of rapidly growing saplings. Under the standard method only the value of the trees is accounted for in the cutting decision process and not the inherent value of the land on which the trees are standing.

${ }^{2}$ It should be noted that in general all types of trees follow a similar growth path. In percentage terms the most rapid growth occurs when the trees are young. In terms of gross amount of growth in volume per year, trees add the most volume to their mass when middleaged. The growth then slows, and eventually the trees stop growing or may even die back as they enter their final stages of life. 
Thus, under the standard model, the slower-growing older trees are left on the land despite the fact that the land could be used to plant a new generation of quick growing trees.

A second interesting item is to note what happens in each model when $r=0$. If the rate of time preference is zero, the obvious desire of the forester is to simply maximize the total wood production of the stand of trees over time without regard to when the wood is harvested. Of course that is exactly the problem the forester solves when finding the maximum MAI. Therefore the optimal harvest rotation when the discount rate is zero should be the same as the harvest length under the maximum MAI. Here again the revised model captures the actions of a truly rational tree-cutter since the optimal cutting period when $r=0$ is equal to the MAI cutting period. The standard model has the logger wait until the tree stand stops growing completely until cutting the trees. For the growth function in this paper, the standard cutting method would result in a $12 \%$ lower harvest of wood over time than would the revised cutting rule.

A final problem of the standard model is its failure to adjust correctly to variations in harvesting and replanting costs. It is intuitive that if the act of harvesting or replanting is costly, then a rational tree-cutter should consciously make a decision to cut and replant the trees less often in order to save the additional costs. With the presence of harvesting costs, $H \geq 0$, and replanting costs, $C \geq 0$, the function for the revised cutting decision is:

$$
\max \sum_{n=1}^{\infty} \frac{V(t)-H-C}{(1+r)^{t n}} \quad \text { w.r.t. } t
$$

The cutting decision for the standard model is not affected by replanting costs, but only the choice whether or not to replant is affected. The standard model reacts to changes in 
harvesting costs in an identical manner to the revised model. Unfortunately, while harvesting costs can be incorporated into the standard model, when this is done the model loses its convenient feature that the cutting rule is where the time when the growth rate $=r$.

Calculations for optimal cutting times and the decision to replant for both the standard and the revised models under the assumption that the harvest costs are still zero but that replanting costs are now present are summarized in Table 2 over a range of discount rates and planting costs

There are several interesting results evident from the data in Table 2. First, as expected the presence of replanting costs increases the harvest length under the optimal model while only changing the replanting decision under the SLP model. Second, the differences between the revised and standard models can be great enough that the actual replanting decision is different for each model. For example, when $C=650$ and $r=.06$, under the standard model it is not worthwhile to replant while under the revised model replanting is now the best policy. Finally, notice that when the decision in the revised model is to not replant, the revised and standard cutting models now match.

The model developed in this paper may serve to explain differences in observed cutting times for privately versus publicly owned forests. The decisions made by individuals may be much different if they are planning to harvest wood from the same area of forest over and over again. Finally, from a purely theoretical point of view, perfectly rational decision makers should always be considering their next step when contemplating any decision. Sequential decision making without forethought is likely to lead to sub-optimal outcomes. 


\section{References}

Alvarez, Luis H. R. And Erkki Koskela, “On the Tree-Cutting Problem under Interest Rate and Forest Value Uncertainty,” CESifo Working Paper No. 870, 2003.

Clawson, Marion, “Decision Making in Timber Production, Harvest, and Marketing,” Research Paper R-4, Washington D.C.: Resources for the Future, 1977, p. 13, Table 1.

Lucas, Robert and Nancy Stokey with Edward Prescott, Recursive Methods in Economic Dynamics, Cambridge, Mass.: Harvard University Press, 1989. 
Table 1

\begin{tabular}{|l|l|l|l|}
\hline Discount Rate & MAI & Standard Method & Revised Method \\
\hline $0 \%$ & 97 years & 135 years & 97 years \\
\hline $2 \%$ & 97 years & 49.3 years & 45 years \\
\hline $4 \%$ & 97 years & 30.7 years & 23 years \\
\hline $6 \%$ & 97 years & 22.0 years & 14 years \\
\hline $8 \%$ & 97 years & 16.9 years & 9 years \\
\hline $10 \%$ & 97 years & 13.6 years & n.a. \\
\hline
\end{tabular}


Table 2

\begin{tabular}{|l|c|c|c|c|c|c|}
\hline $\begin{array}{l}\text { Discount } \\
\text { Rate, } r\end{array}$ & $\begin{array}{c}\text { Standard } \\
\mathrm{C}=0\end{array}$ & $\begin{array}{c}\text { Revised } \\
C=0\end{array}$ & $\begin{array}{c}\text { Standard } \\
\mathrm{C}=650\end{array}$ & $\begin{array}{c}\text { Revised } \\
\mathrm{C}=650\end{array}$ & $\begin{array}{c}\text { Standard } \\
\mathrm{C}=1200\end{array}$ & $\begin{array}{c}\text { Revised } \\
\mathrm{C}=1200\end{array}$ \\
\hline $0 \%$ & $\begin{array}{c}135.3 \text { years } \\
\text { Replant }\end{array}$ & $\begin{array}{c}97 \text { years } \\
\text { Replant }\end{array}$ & $\begin{array}{c}135.3 \text { years } \\
\text { Replant }\end{array}$ & $\begin{array}{c}99.5 \text { years } \\
\text { Replant }\end{array}$ & $\begin{array}{c}135.3 \text { years } \\
\text { Replant }\end{array}$ & $\begin{array}{c}100.3 \text { years } \\
\text { Replant }\end{array}$ \\
\hline $2 \%$ & $\begin{array}{c}49.3 \text { years } \\
\text { Replant }\end{array}$ & $\begin{array}{c}45 \text { years } \\
\text { Replant }\end{array}$ & $\begin{array}{c}49.3 \text { years } \\
\text { Replant }\end{array}$ & $\begin{array}{c}51.9 \text { years } \\
\text { Replant }\end{array}$ & $\begin{array}{c}49.3 \text { years } \\
\text { Replant }\end{array}$ & $\begin{array}{c}56.4 \text { years } \\
\text { Replant }\end{array}$ \\
\hline $4 \%$ & $\begin{array}{c}30.7 \text { years } \\
\text { Replant }\end{array}$ & $\begin{array}{c}23 \text { years } \\
\text { Replant }\end{array}$ & $\begin{array}{c}\text { 30.7 years } \\
\text { Replant }\end{array}$ & $\begin{array}{c}34.0 \text { years } \\
\text { Replant }\end{array}$ & $\begin{array}{c}30.7 \text { years } \\
\text { No Replant }\end{array}$ & $\begin{array}{c}39.4 \text { years } \\
\text { Replant }\end{array}$ \\
\hline $6 \%$ & $\begin{array}{c}22.0 \text { years } \\
\text { Replant }\end{array}$ & $\begin{array}{c}14 \text { years } \\
\text { Replant }\end{array}$ & $\begin{array}{c}22.0 \text { years } \\
\text { No Replant }\end{array}$ & $\begin{array}{c}26.7 \text { years } \\
\text { Replant }\end{array}$ & $\begin{array}{c}22.0 \text { years } \\
\text { No Replant }\end{array}$ & $\begin{array}{c}22.0 \text { years } \\
\text { No Replant }\end{array}$ \\
\hline 8.9 years & 9 years & $\begin{array}{c}16.9 \text { years } \\
\text { Re Replant }\end{array}$ & $\begin{array}{c}16.9 \text { years } \\
\text { No replant }\end{array}$ & $\begin{array}{c}16.9 \text { years } \\
\text { No Replant }\end{array}$ & $\begin{array}{c}16.9 \text { years } \\
\text { No replant }\end{array}$ \\
\hline
\end{tabular}

